\title{
Antigliadin antibody measurement by chemiluminescence ELISA in the diagnosis of coeliac disease
}

\author{
S R Merridew, D V Wilson, E J Williams
}

\begin{abstract}
Aims-To develop a chemiluminescence enzyme linked immunosorbent assay (ELISA) for the detection of circulating gliadin antibodies in the diagnosis of coeliac disease. To compare this method for linearity and sensitivity with an established colorimetric method.

Methods-Three sets of age and sex matched patient groups were studied: normal controls (patients with no clinical signs of intestinal disorders); gastrointestinal controls (patients with a known gastrointestinal disorder other than coeliac disease); and patients in whom suspected coeliac disease had been confirmed by positive jejunal biopsy. IgG antigliadin antibody (IgG-AGA) and IgA antigliadin antibody (IgA-AGA) titres were determined.

Results-Comparison of the colorimetric and chemiluminescence methods showed close correlation of measured antibody levels for both control patient groups. In the coeliac patients correlation of antibody levels measured by both methods was not possible because the colorimetric assay is limited by the spectrophotometer's limits of detection. This problem was overcome by the chemiluminescence method which was linear over a greater range and to far higher values.

Conclusions-The chemiluminescence ELISA performs as well as the colorimetric assay at low and average antibody levels and has the advantage of also giving a numerical value to higher antibody titres. The method was accurate and reproducible in confirming the diagnosis of coeliac disease in patients with positive jejunal biopsy and was capable of monitoring progress of the disease.

(f Clin Pathol 1995;48:509-512)
\end{abstract}

Keywords: Antigliadin antibodies, ELISA, chemiluminescence, coeliac disease.

In the 1950s Dicke ${ }^{1}$ observed that the wheat protein, gluten, was probably the agent causing coeliac disease. Since then, much work has been undertaken to determine the exact patho- genesis of the disease..$^{2-4}$ Due to the gross destruction of gut villous structure in coeliac disease, the absorptive area of the gut becomes increasingly more permeable to macromolecules which in turn leads to enhanced antibody production to various food proteins; gliadin, the ethanol soluble fraction of wheat gluten, ${ }^{5}$ is one of the most important of these.

A variety of methods have been used to detect wheat protein antibodies in serum samples ranging from haemagglutination, ${ }^{6}$ fluorescence, ${ }^{7}$ radioimmunoassay $^{8}$ to enzyme linked immunosorbent assay (ELISA) methods. ${ }^{910}$ Most ELISA methods published to date have colorimetry as their end point detection and results are expressed either as an enzyme index or as changes in optical density readings. Both methods of expression have disadvantages when testing samples with high end point colour as under these circumstances, deviations from Beer-Lambert's law may occur. The fact that chemiluminescence generally shows no linear restriction fully justifies the development of a method based on it to overcome the inability of other methods to quantify high antibody values without re-optimising method conditions.

We report a method evolved from the colorimetric assay of O'Farrelly et al, ${ }^{11}$ adapted for the estimation of gliadin antibodies on the Kodak Amerlite System and using chemiluminescence detection. The new method is an effective procedure for estimating serum IgG and IgA antibodies to gliadin. It should be capable of extension to measure antibodies of other classes and subclasses, and to the examination of other body fluids.

\section{Methods}

Normal serum samples $(n=100)$ were used in both colorimetric and chemiluminescence methodologies to set reference ranges for both IgG and IgA gliadin antibodies.

Experimental serum samples were obtained from 20 patients in whom coeliac disease was diagnosed by demonstrating hyperplastic villous atrophy, hyperplasia of the crypts and plasma cell infiltration of the lamina propria in jejunal biopsy samples. The mean age of the group was 39 years ranging from two to 73 


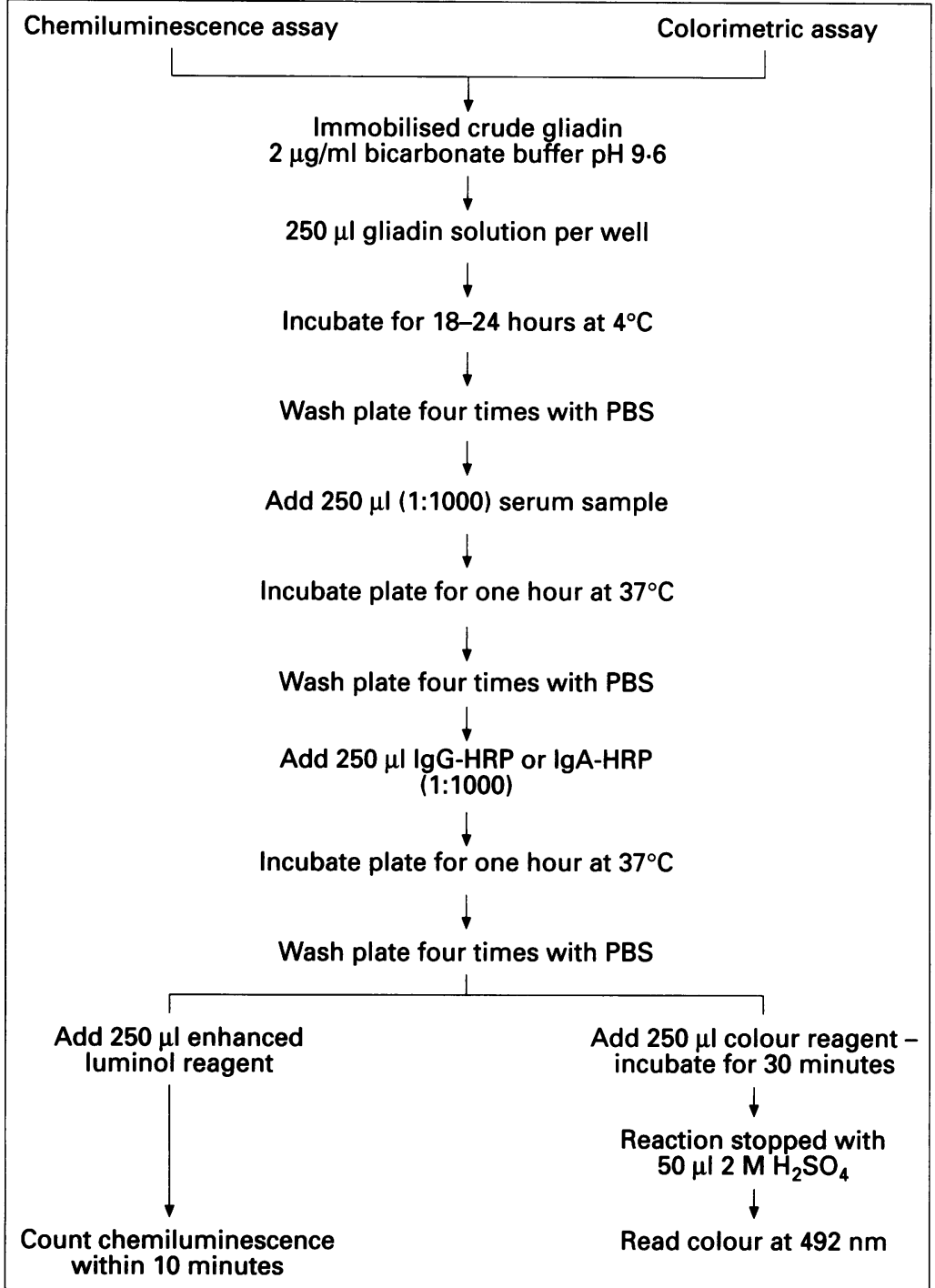

Figure 1 Optimised assay protocols for colorimetric and chemiluminescence ELISA estimations of serum gliadin antibodies.

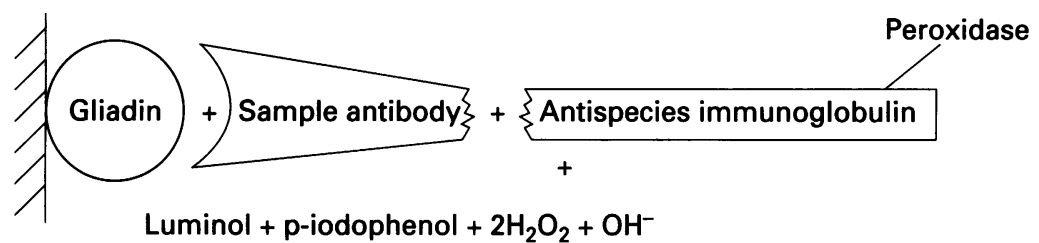

Luminol $+\mathrm{p}$-iodophenol $+2 \mathrm{H}_{2} \mathrm{O}_{2}+\mathrm{OH}^{-}$
Aminophthalic acid $+\mathrm{N}_{2}+\mathrm{H}_{2} \mathrm{O}+$ Light $(\max =430 \mathrm{~nm})$

Figure $2 A$ schematic diagram showing the principle of luminescence immunoassay and the products obtained upon oxidation of luminol.

years with a ratio of seven males to 13 females. All serum samples in this group were obtained while the patients were on a normal gluten containing diet.

Two groups of control serum samples were examined: 20 "normal controls" (patients with disorders other than gastrointestinal diseases) and 20 "gastrointestinal controls" (patients with gastrointestinal disorders-for example, Crohn's disease, colitis). Patients in each group were well matched for age and sex.

Serum samples from all subjects were stored in $200 \mu \mathrm{l}$ aliquots at $-20^{\circ} \mathrm{C}$. The samples were thawed for one hour before assay of gliadin antibodies (IgG and IgA) by both colorimetric and chemiluminescence methods.

Apparatus-A Kodak Amerlite analyser incorporating an Amerlite plate washer and reader (Kodak Clinical Diagnostics Ltd, Amersham, UK); Dynatech microtitre wells (Dynatech UK Ltd, Billinghurst, Sussex, UK): Dynalume MTP (white) (M411912/W); photometric ELISA plate reader (LabSystems Uniskan III; Labsystems UK Ltd, Basingstoke, UK); and colorimetric microtitre wells (Corning): disposable ELISA (25801 FB).

Reagents-Antigen was crude gliadin (batch no. 35F-8160; Sigma, Poole, Dorset, UK). Enzyme labelled antibodies were purchased from Dako (High Wycombe, UK) as horseradish peroxidase (HRP) conjugated rabbit antihuman IgG (IgG-HRP) and antihuman IgA (IgA-HRP). The chemiluminescent signal reagent was an enhanced luminol derivative ( $p$ iodophenol and luminol) (Kodak Clinical Diagnostics). The substrate used in the colorimetric ELISA was ortho-phenylene diamine (Sigma); the reaction was stopped with $2 \mathrm{M}$ $\mathrm{H}_{2} \mathrm{SO}_{4}$ (prepared from Analar Conc).

Buffers-Carbonate/hydrogen carbonate $(0.1 \mathrm{M}, \mathrm{pH} 9.6)$ freshly prepared before assay. Phosphate buffered saline (PBS) $(0.1 \mathrm{M}, \mathrm{pH}$ $7 \cdot 4)$ with added Tween-20 $(0.5 \mathrm{ml} / \mathrm{l})$, freshly prepared before assay.

PROTOCOL FOR OPTIMISED ELISA ESTIMATION OF SERUM GLIADIN ANTIBODIES

All antibody assays were performed in 96 well microtitre plates. Gliadin ( $2 \mathrm{mg}$ ) was dissolved in $1 \mathrm{ml} 0.1 \mathrm{M}$ acetic acid and then diluted ( 1 in 1000) in carbonate/hydrogen carbonate buffer $(0 \cdot 1 \mathrm{M}, \mathrm{pH} \mathrm{9.6)}$ to give a concentration of $2 \mu \mathrm{g} / \mathrm{ml}$. Each well received $250 \mu \mathrm{l}$ of this solution. After incubation at $4^{\circ} \mathrm{C}$ for 18 to 24 hours, the wells were washed four times with PBS. The test serum samples were diluted 1 in 1000 with PBS immediately before use and $250 \mu \mathrm{l}$ was added to a coated well and incubated for one hour at $37^{\circ} \mathrm{C}$. The wells were again washed four times with PBS and then $250 \mu$ lof IgG (or IgA)-HRP diluted 1 in 1000 in PBS was added to each well and incubation was continued for a further hour at $37^{\circ} \mathrm{C}$. A schematic representation of the assay protocols is illustrated in fig 1.

In the chemiluminescence protocol the wash procedure was repeated and, finally, $250 \mu \mathrm{l}$ of the enhanced luminol signal reagent was added to each well. After 10 minutes at room temperature, the chemiluminescence produced by each sample was measured using the Amerlite analyser. Chemiluminescence is the production of light by peroxidase catalysed oxidation of luminol as illustrated in fig 2 .

The colorimetric ELISA estimation of serum gliadin antibodies was carried out as described by O'Farrelly et al. ${ }^{11}$ Following the initial protocol as for the chemiluminescence method, substrate $(250 \mu \mathrm{l})$ was added and incubated at room temperature for 30 minutes. The reaction was stopped with $2 \mathrm{M} \mathrm{H}_{2} \mathrm{SO}_{4}(50 \mu \mathrm{l})$ and the colour read on the plate reader at $492 \mathrm{~nm}$. 
Intrabatch $C V$ calculated at three antigliadin antibody titres (low, middle and high) where $n=5$.

\begin{tabular}{|c|c|c|c|c|}
\hline \multirow[b]{2}{*}{ Antigliadin antibody titre } & \multicolumn{2}{|c|}{$\begin{array}{l}\text { Chemiluminescence } \\
\text { method }\end{array}$} & \multicolumn{2}{|l|}{$\begin{array}{l}\text { Colorimetric } \\
\text { method }\end{array}$} \\
\hline & Mean (AEI) & $\% C V$ & Mean (EI) & $\% C V$ \\
\hline \multicolumn{5}{|l|}{ IgG-AGA } \\
\hline $\begin{array}{l}\text { low } \\
\text { middle } \\
\text { high }\end{array}$ & $\begin{array}{c}1 \cdot 478 \\
7 \cdot 962 \\
29 \cdot 26\end{array}$ & $\begin{array}{l}6 \cdot 43 \\
3 \cdot 45 \\
1 \cdot 75\end{array}$ & $\begin{array}{l}1.688 \\
6.556 \\
34.98\end{array}$ & $\begin{array}{l}6 \cdot 46 \\
4 \cdot 68 \\
3 \cdot 40\end{array}$ \\
\hline $\begin{array}{l}\text { IgA-AGA } \\
\text { low } \\
\text { middle } \\
\text { high }\end{array}$ & $\begin{array}{c}0 \cdot 502 \\
9 \cdot 092 \\
27 \cdot 46\end{array}$ & $\begin{array}{l}5 \cdot 58 \\
2 \cdot 77 \\
2 \cdot 87\end{array}$ & $\begin{array}{c}1 \cdot 256 \\
8 \cdot 890 \\
17.98\end{array}$ & $\begin{array}{l}5 \cdot 65 \\
4 \cdot 89 \\
2 \cdot 65\end{array}$ \\
\hline
\end{tabular}
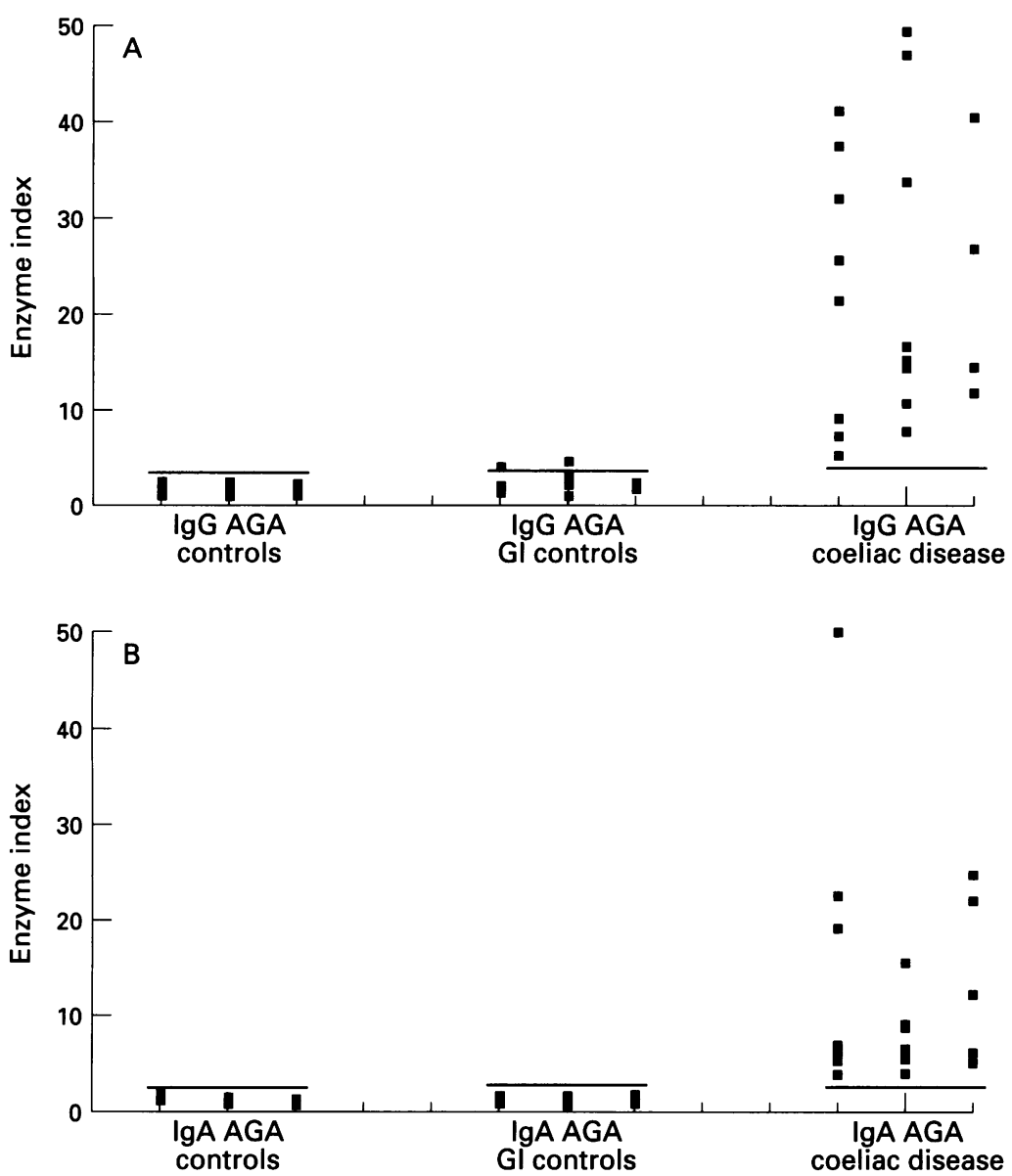

Figure 3 Distribution of serum antigliadin antibodies in a normal control population $(n=20)$, in patients with other gastrointestinal (GI) disorders $(n=20)$, and untreated coeliac disease $(n=20)$. All of these EIs were estimated by the chemiluminescence ELISA method. A: Serum IgG-AGA upper limit of normal, $E I=2 \cdot 7$. B: Serum IgA-AGA upper limit of normal, $E I=2 \cdot 0$.

For both assays, the first three wells of each plate were blanks containing PBS $(250 \mu \mathrm{l})$ which replaced the diluted serum. At least two other blank triplicates were set up at variable points on the plate to avoid the "edge effect" commonly seen in ELISA methods. Each sample to be assayed was set up in triplicate and the analyser readings used to calculate the results. Antibody binding was expressed as the ELISA index (EI). Quantifying absolute antibody concentration was not attempted, as antibodies to such a heterogenous compound as gliadin may have noticeably differing structures and avidities. The enzyme index was calculated as follows:

\section{$\mathrm{EI}=\frac{\text { Mean of light index reading of test in triplicate }}{\text { Mean }}$ \\ Mean of light index reading of blank in triplicate}

Each assay was controlled for quality using serum samples of known high antibody titre and high EI. The assay was accepted if the calculated control value came within $10 \%$ of the mean of the previous assay results.

\section{Results}

The reference ranges were established by estimating IgG and IgA antigliadin antibodies (IgG-AGA, IgA-AGA) using a large number of normal serum samples $(n=100)$. The IgGAGA EI range was 0 to 3.0 for the colorimetric assay and 0 to $2 \cdot 7$ for the chemiluminescence assay. For IgA-AGA, the colorimetric assay and the chemiluminescence assay ranges were both 0 to $2 \cdot 0$. In this study the 20 "normal controls" gave a normal EI distribution for both IgG-AGA and IgA-AGA when estimated by both methods. The chemiluminescence assay compared favourably with the colorimetric assay, giving correlation values of $r=0.901$ for IgG-AGA and $r=0.913$ for IgA-AGA. The gastrointestinal controls gave correlation values of $r=0.975$ for IgG-AGA and $r=0.932$ for IgA-AGA. Correlation for the two control groups taken as a whole gave values of $r=0.970$ for IgG-AGA and $r=0.925$ for IgA-AGA.

In the patients with coelic disease, confirmed on jejunal biopsy, ${ }^{12}$ correlation of EIs for the two methods was not possible because the colorimetric assay was curtailed by the spectrophotometer's limits of detection.

Intrabatch coefficients of variation (CV) were calculated at three antibody titres for both methods (table).

Interbatch CVs were calculated for the chemiluminescence method giving values of 2.95 and 7.0 for IgG-AGA and IgA-AGA, respectively, and 5.33 and 9.7 for the colorimetric assay.

Both IgG-AGA and IgA-AGA show a clear demarcation of EI values separating the control serum samples from those of the patients with coeliac disease (fig 3 ).

\section{Discussion}

The chemiluminescence method described here confirms that both IgG and IgA antibodies to gliadin are significantly raised in patients with untreated coeliac disease. The chemiluminesence method is not difficult to perform, is easily automated and has the advantage of being economical with reagents. The method is sensitive, giving a numerical value which is reproducible and is a useful measure of the degree of immunological response to gluten. It may be considered less hazardous than the established colorimetric assay as the substrate, o-phenylene diamine, has now been reported to be a carcinogen.

The results of this study indicate that in cases of untreated coeliac disease, reliable diagnostic conclusions may be drawn by measuring antigliadin antibodies using the chemiluminescence method. Both IgG and IgA serum gliadin antibody titres were elevated in cases where the diagnosis of coeliac disease had been confirmed by a jejunal biopsy thus complying with the Working Group of the European Society of Paediatric Gastroenterology and Nutrition criteria. ${ }^{13}$ Neither a further biopsy nor 
a gluten challenge were undertaken as this was not considered necessary where the biopsy was conclusive. ${ }^{13}$

Elevated IgG-AGA titres were seen in a few patients with gastrointestinal disorders other than coeliac disease-for example, other food intolerances. These patients had abnormal jejunal mucosae on biopsy, but histology was not consistent with coeliac disease. Measurement of serum IgG-AGA titres, however, was less sensitive with a specificity in the noncoeliac disease group of $90 \%$. Measurement of IgA-AGA and IgG-AGA titres in those with coeliac disease resulted in $100 \%$ sensitivity.

The greater linearity and wider measurement range of the chemiluminescence method permits quantification of gliadin antibodies at higher titres and thus provides a method for monitoring the progress of treatment in patients with confirmed coeliac disease-for example, compliance to, and the rate of response to, a gluten free diet are easily measured.

More recently, we have successfully applied the method to salivary samples and hope that it will be of even greater diagnostic value in paediatric patients.
1 Dicke WK, Weijers HA, Van de Kamer JH. Coeliac disease II. The presence in wheat of a factor having a deleterious effect in cases of Coeliac disease. Acta Paediatr 1953;42: $34-42$.

2 Cole SG, Kagnoff MF. Celiac Disease. Ann Rev Nutr 1985; 5:241-66.

3 Holmes GKT, Ching CK. Coeliac Disease in the 1990s. Gastroenterology 1990;9:127-33.

4 Ciclitira PJ, Ellis HJ. Investigation of cereal toxicity in coeliac disease. Postgrad Med f 1987;63:767-75.

5 Cooke WT, Holmes GKT. The jejunal mucosa. In: Coeliac disease. London: Churchill Livingstone, 1984:23-66.

6 Taylor KB, Thomson DL, Trulove SC, Wright R. An immunological study of coeliac disease and idiopathic immunological study of coeliac disease and idiopathic steatorrhoea. Serological reactions

7 Burguin-Wolff A, Bertele RM, Berger R, Gaze H, Harms HK, Just $M$, et al. A reliable screening test for childhood coeliac disease: Fluorescent immunosorbent test for gliadin antibodies. F Pediatr 1983;102:655-60.

8 Ciclitira PJ, Ellis HJ, Evans DJ. A solid-phase radioimmunoassay for measurement of circulating antibody adult coeliac disease. F Immunol Methods 1983;62:231-9.

9 Kelly CP, Feighery CF, Weir DG. Biotin-Streptavidin ELISA: A sensitive, standardised assay for serum antiELISA: A sensitive, standardised assay for serum anti-
gliadin IgA in Coeliac Disease [abstract]. Gastroenterology 1988;94:A221.

10 Hill PG, Thompson SP, Holmes GKT. IgA antigliadin antibodies in adult coeliac disease. Clin Chem 1991;37:647-50.

11 O'Farrelly C, Kelly J, Hekkens W, Bradley B, Thomson A, Weir DG. Alpha-gliadin antibody levels: a serological test for coeliac disease. BMF 1983;286:2007-10.

12 Lee FD, Toner PG. Diffuse villous abnormality In: Biopsy pathology of the small intestine. London: Chapman Hall, 1980:97-119.

13 Report of Working Group of European Society of Paediatric Gastroenterology and Nutrition. Revised Criteria for diagnosis of coeliac disease. Arch Dis Child 1990;65:909-11. 